\title{
CALCIFICATION OF THE DIGITAL VESSELS IN A CHILD WITH RHEUMATOID ARTHRITIS
}

\author{
BY \\ CONSTANCE C. FORSYTH \\ From the Department of Child Health, University of St. Andrews, Queen's College, Dundee
}

(RECEIVED FOR PUBLICATION JULY 6, 1959)

Calcification of blood vessels occurring during the course of rheumatoid arthritis in a child appears to be unique. It is hoped therefore that this report will be of interest.

\section{Case History}

The girl is now 9 years old. Her illness began at the age of 2 years with fever, joint swellings, pericarditis with effusion, rash, splenomegaly, lymphadenopathy and anaemia, indeed the full clinical picture of Still's disease (1897). There was a family history of rheumatic fever on both the paternal and maternal sides but none of rheumatoid arthritis. She was treated along conservative lines in the Royal Hospital for Sick Children, Edinburgh, for one year and then, during her second year there, she was given $20 \mathrm{mg}$. of A.C.T.H. gel daily for six months followed by $25 \mathrm{mg}$. of A.C.T.H. gel every second day for six months. Only slight improvement was noted and later it was found that she could be just as well controlled on $50 \mathrm{gr}$. of aspirin daily. By the time of her discharge home the heart had returned to normal but the joints of all four limbs were still affected and also the cervical spine. She could walk a little with support.

The family moved to Dundee shortly afterwards. One month later, at the age of $4 \frac{1}{2}$ years, she was admitted to Dundee Royal Infirmary with a recurrence of pericarditis and widespread acute arthritis. During the ensuing eight months of complete bed-rest, despite such physiotherapy as she could tolerate, the condition of the joints deteriorated. When the pericarditis had resolved, after rather a stormy course with heart failure, the child was transferred to the Children's Orthopaedic Unit so that serial plasters could be made to improve the position of her joints, in which movement was very limited. She was there for five months but again her general condition gave cause for anxiety and she was returned to the paediatric ward.

It was then evident that after three years of active rheumatoid arthritis she had developed amyloid disease. The liver was more than a hand's breadth enlarged and the spleen three fingers' breadths enlarged. There was gross albuminuria (between $600 \mathrm{mg}$. $/ 100 \mathrm{ml}$. and 1,200 mg. $/ 100 \mathrm{ml}$.) in the 24-hour samples. None of these findings had been present six months previously. No biopsy was taken as neither the skin nor the lymph nodes were involved, but the Congo red test showed 95\% fixation of dye by the tissues in one hour. Although the heart was again clinically normal the arthritis had become even more severe. There was marked dilatation of capillaries at the base of the nails. She could not grasp objects with her hands or move them to her mouth and she could not stand or attempt to walk. Her neck was fixed and her back rigid. Her general condition was poor; she was miserable and suffering a great deal of pain. It was therefore decided to try hormone therapy again. Relatively higher dosage was given on this occasion, namely $\mathbf{2 0} \mathrm{mg}$. prednisolone daily for four weeks followed by a gradual reduction to $10 \mathrm{mg}$. daily. The improvement was striking. Within two months she could feed herself and walk slowly on her own. The B.S.R. fell to normal and remained so for the first time since the onset of her illness. Long term therapy had therefore to be considered.

In order that a check might be kept on the osteoporotic effect of hormone therapy, radiographs were taken of the entire skeleton. These showed gross generalized skeletal decalcification with fusion of the inter-articular processes of the cervical spine and collapse of the fourth to the tenth thoracic vertebrae inclusive (Fig. 1). The lumbar vertebrae were normal. Previous films had shown a normal cervical spine at 3 years but early fusion of the inter-articular processes was present at $4 \frac{1}{2}$ years when she was first examined radiologically in Dundee. On neither occasion had a radiograph of the thoracic spine been ordered but one film taken at $4 \frac{1}{2}$ years showed collapse of the fourth to the seventh thoracic vertebrae at which point the film was cut off. In addition to the generalized skeletal decalcification there was calcification of the digital blood vessels of the hands and feet (Figs. 2 and 3), almost certainly arterial, although arteriography would have been necessary to prove it. A radiograph of the hands two years previously had shown some osteoporosis around the affected joints but no calcification of the digital vessels. By this time the child had been given a total of $1.47 \mathrm{~g}$. of prednisolone. In spite of the vertebral collapse and severe osteoporosis it was decided 




FIG. 1.-Radiograph of spine showing osteoporosis and deformity of

FIG. 2.-Radiograph of hands showing calcification of the digital blood vessels.

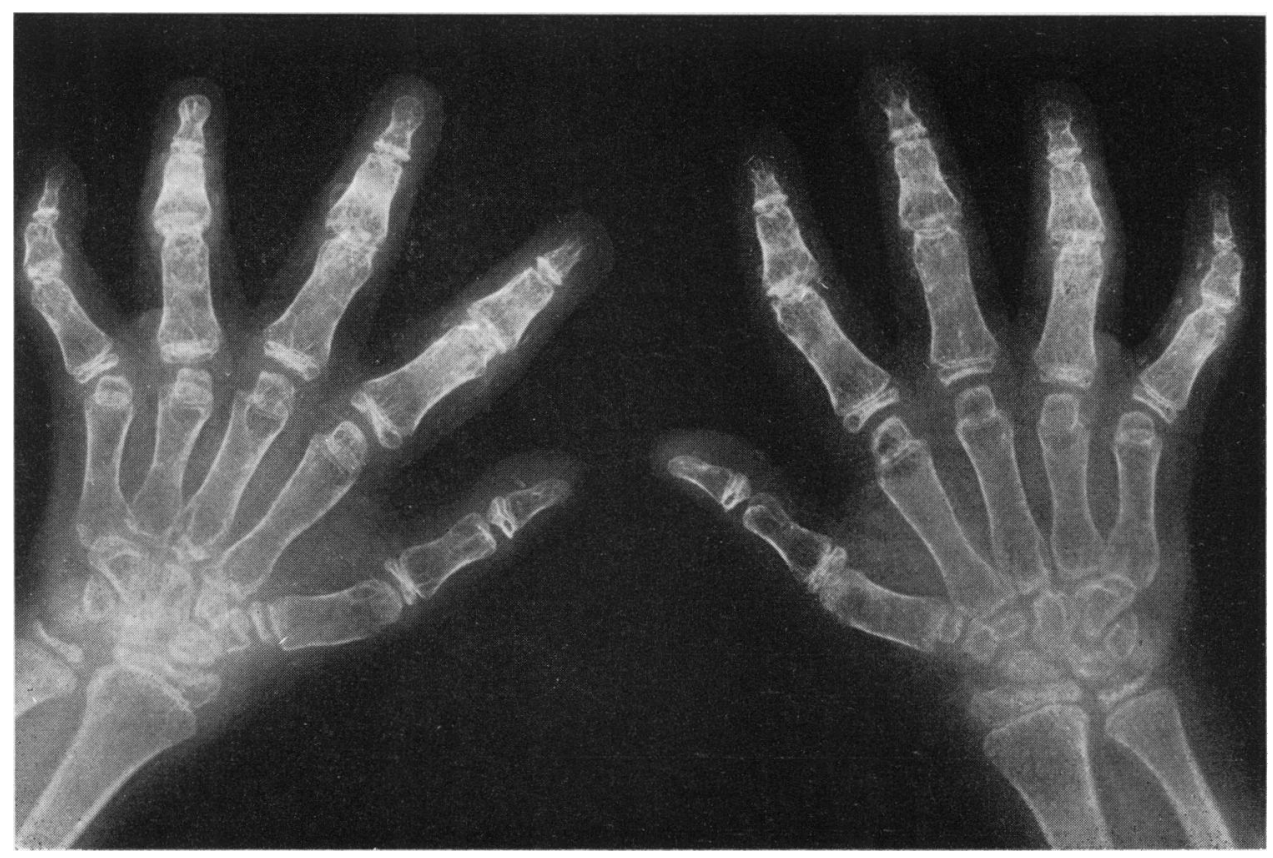




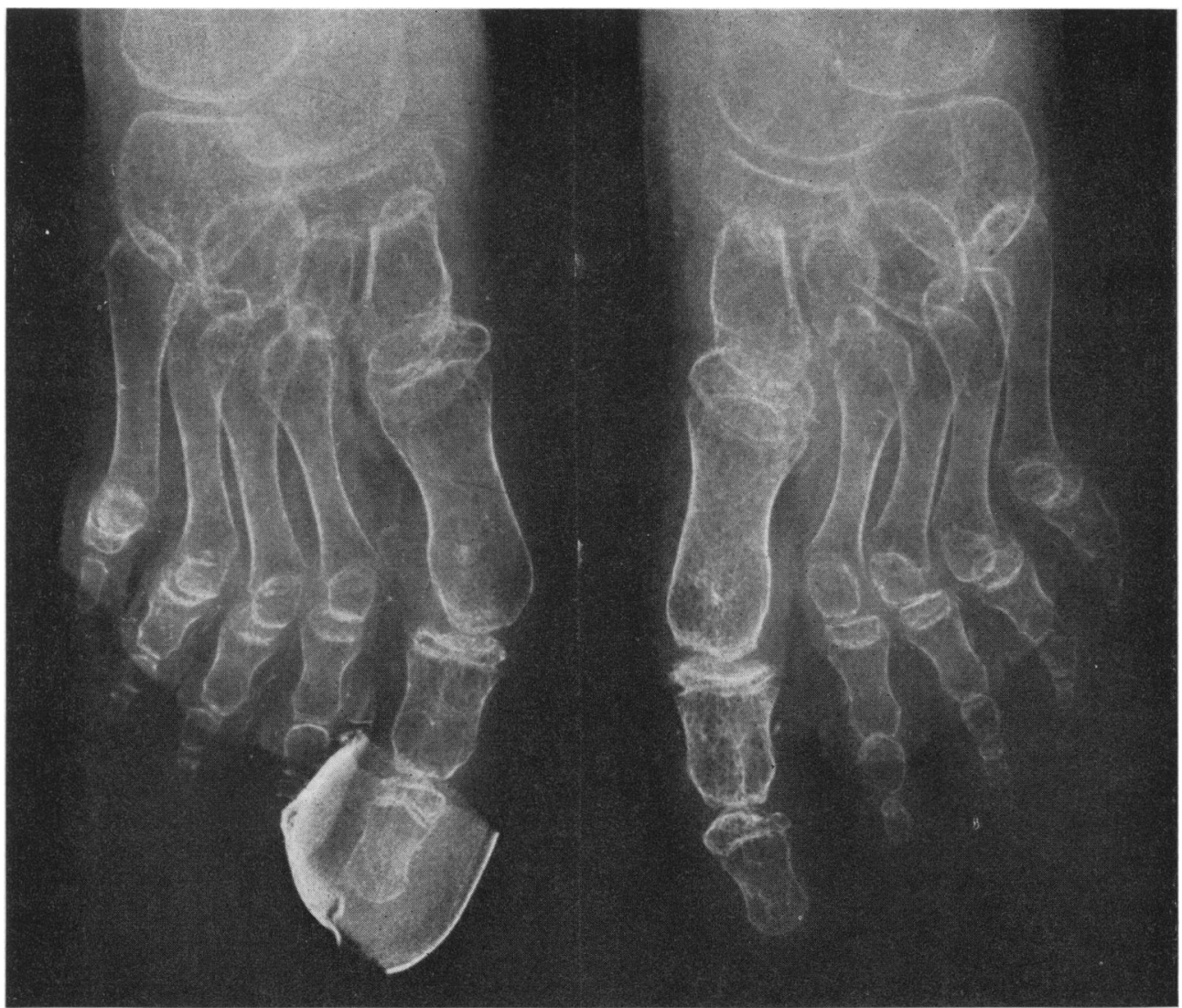

FIG. 3.-Radiograph of feet showing calcification of the digital blood vessels and the first right metatarsal artery.

$$
\text { st }
$$

to continue hormone therapy in view of the striking clinical improvement obtained.

A calcium balance was then undertaken to see whether the use of methylandrostenediol would increase the retention of body calcium (Fischer and Hastrup, 1954). The results are summarized in Table 1 for the balance period of 30 days. The diet which the child had been taking for some time and which contained a large amount of milk was first analysed and then kept con-

TABLE 1

\begin{tabular}{|c|c|c|c|c|c|}
\hline & \multicolumn{4}{|c|}{ Average Daily } & \multirow{3}{*}{$\begin{array}{c}\text { Percentage } \\
\text { Daily } \\
\text { Retention }\end{array}$} \\
\hline & \multirow{2}{*}{$\begin{array}{c}\text { Intake } \\
\text { (mg.) }\end{array}$} & \multicolumn{2}{|c|}{ Output } & \multirow{2}{*}{\begin{tabular}{|} 
Retention \\
(mg.)
\end{tabular}} & \\
\hline & & $\begin{array}{l}\text { Urine } \\
\text { (mg.) }\end{array}$ & $\begin{array}{l}\text { Stool } \\
\text { (mg.) }\end{array}$ & & \\
\hline $\begin{array}{l}\text { Calcium } \\
\text { Phosphorus }\end{array}$ & $\begin{array}{r}1,140 \\
993\end{array}$ & $\begin{array}{r}27 \\
134\end{array}$ & $\begin{array}{l}439 \\
316\end{array}$ & $\begin{array}{l}674 \\
543\end{array}$ & $\begin{array}{l}59 \\
55\end{array}$ \\
\hline
\end{tabular}

\section{RETENTION OF BODY CALCIUM AND PHOSPHORUS}

stant. She had not been having vitamin D supplements and none were given during the balance. The calcium balance was carried out for 10 days on $10 \mathrm{mg}$. of prednisolone daily. On the eleventh day methylandrostenediol, $30 \mathrm{mg}$. daily, was added and the balance was continued for another 20 days. No change in calcium or phosphorus retention due to the methylandrostenediol was noted. The calcium and phosphorus balances were very strongly positive throughout the whole period. The average calcium retention by children of early school age was reported as $26 \%$ of the intake by Holmes (1945). This child was retaining $59 \%$ of her calcium intake.

The considerable retention of calcium in spite of continued prednisolone therapy was thought to be due to the process of recalcification of the skeleton brought about by increased exercise. The calcium balance had presumably been negative during the protracted period of bed rest. The biochemical findings at the time of the balance are summarized in Table 2 . The only abnormality was a rise in globulin to $4 \cdot 2 \mathrm{~g} . / 100 \mathrm{ml}$. with a normal albumin of $4 \cdot 2 \mathrm{~g} . / 100 \mathrm{ml}$. Electrophoresis showed an increase in $\alpha_{2}$ and $\gamma$ globulins consistent with some 
activity of the rheumatoid arthritis. The B.S.R. was $18 \mathrm{~mm}$./hour (Westergren) on the same blood sample.

TABLE 2

BIOCHEMICAL FINDINGS

\begin{tabular}{ll}
\hline Calcium & $=10.6 \mathrm{mg} . / 100 \mathrm{ml}$. \\
Phosphorus & $=3.8 \mathrm{mg} . / 100 \mathrm{ml}$. \\
Alkaline phosphatase & $=16 \mathrm{~K}$. A. units $/ 100 \mathrm{ml}$. \\
& $=20 \mathrm{mg} . / 100 \mathrm{ml}$. \\
Urea & $=180 \mathrm{mg} . / 100 \mathrm{ml}$. \\
Bilirubin & $=0.5 \mathrm{mg} . / 100 \mathrm{ml}$. \\
Sodium & $=139 \mathrm{mEq} . / 1$. \\
Potassium & $=4.8 \mathrm{mEq} . / 1$. \\
Chloride & $=99 \mathrm{mEq} . / 1$. \\
Albumin & $=4.2 \mathrm{~g} . / 100 \mathrm{ml}$. \\
Globulin & $=4.2 \mathrm{~g} . / 100 \mathrm{ml}$. \\
Total & $=8.4 \mathrm{~g} . / 100 \mathrm{ml}$. \\
\end{tabular}

After five months' treatment with prednisolone the child was able to wash and feed herself and walk on her own and so she was allowed to go home. At home she has continued to improve gradually on prednisolone therapy, $10 \mathrm{mg}$. daily for two years and, more recently, on $7.5 \mathrm{mg}$. daily. She can now walk a quarter of a mile. During this period the amyloidosis has regressed with much diminution in the size of the liver and spleen and a reduction of the albuminuria to $25 \mathrm{mg} .100 \mathrm{ml}$. in the 24-hour collections. As previously given, the Congo red test in January, 1955 showed $95 \%$ fixation of dye by the tissues at the end of one hour. In May, 1956 the fixation was $87 \%$, in December, 1956 it was $75 \%$, in March, 1958 it was $56 \%$ and in March, 1959 it was $65 \%$. Recent radiographs show that general recalcification of the skeleton has taken place although it is not yet normally calcified. There is in addition a diminution in the calcification of the digital vessels. At no time has the blood flow to the digits appeared deficient. On the contrary, one persistent sign of activity has been the dilatation of capillaries at the base of the nails. The skin has never shown any thickening suggestive of dermatomyositis, however, and there were no lupus erythematosus cells in the blood samples examined.

The blood pressure is now $130 / 100 \mathrm{~mm}$. $\mathrm{Hg}$, whereas before A.C.T.H. therapy it was $110 / 80 \mathrm{~mm}$. Hg. While $20 \mathrm{mg}$. of prednisolone was being given daily it was $150 / 120 \mathrm{~mm}$. $\mathrm{Hg}$.

The child's growth has been retarded since the onset of her illness. Even during this last year when she has been in better health than in previous years there has been an increment of $\frac{1}{2}$ in. Only in height. The height of 43 in. at 9 years is well below the third percentile and the weight of $47 \mathrm{lb}$. is at the third percentile. Her weight has been kept reasonable by slight dietetic restriction. The bone age, judged by the maturation of the skeleton as a whole, is 13 years, i.e. four years in advance, and menstruation occurred abnormally early at the age of 8 years. Pubic hair is present but no axillary hair has appeared. There is early breast enlargement (Fig. 4).

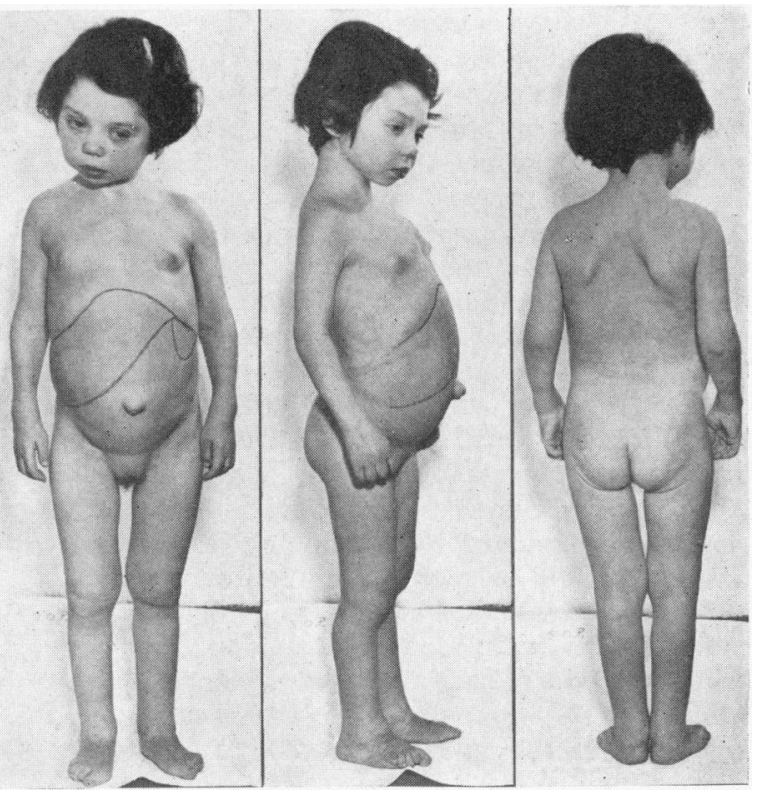

FiG. 4.-Patient aged 9 years.

To summarize, this child has suffered from active rheumatoid arthritis for seven years. During the course of her illness pericarditis has occurred twice. She has developed amyloidosis and gross decalcification of the skeleton with vertebral collapse and calcification of the digital vessels. Prednisolone therapy, even at a late stage, led to a marked improvement in her condition.

\section{Discussion}

It is interesting that prednisolone therapy produced so much improvement in this child after four years of severe rheumatoid arthritis, when A.C.T.H. gel, admittedly in relatively smaller dosage, was ineffective in the early stages. The hypertension is probably due to prednisolone but it should be noted that the blood pressure tended to be high even before A.C.T.H. was first given. Early menstruation may also be the result of hormone therapy. Stunting of growth due to the disease would be expected but may have been accentuated by prednisolone. The disparity between the stunting and the advanced bone age is difficult to explain, although the advanced bone age and early menstruation may be related pituitary effects. Amyloidosis is a rare, although recognized, complication of rheumatoid arthritis in childhood. Its regression with improvement in the rheumatoid condition has been described by Parkins and Bywaters (1959).

The vertebral collapse was first noted at the age of $4 \frac{1}{2}$ years following one year's treatment with 
A.C.T.H. in very moderate dosage. It is unfortunate that radiographs were not taken immediately before prednisolone therapy was begun because in retrospect it is not possible to separate the possible effect of the hormone from that of immobilization in producing generalized decalcification of the skeleton and concomitant calcification of the digital vessels. No other tissues appear to be involved in the process of metastatic calcification. I think that the severe decalcification was chiefly due to prolonged bed-rest with almost complete immobilization of the joints due to rheumatoid arthritis and possibly not at all to A.C.T.H. or prednisolone therapy in view of the small to moderate dosage employed (Welch and Forsyth, 1953; Luder, 1954). This view is substantiated by the finding of a strongly positive calcium balance in the month in which the radiographs were taken and by the gradual recalcification of the skeleton which followed during the next three years of continuous prednisolone therapy. Along with this improvement in skeletal calcification it is of interest to note the diminution in calcification of the digital vessels.

Regarding the aetiology of the calcification of the digital vessels, several possibilities must be considered.

Although amyloidosis affects blood vessels, calcification of the deposits in the vessel walls does not occur.

Calcification of peripheral vessels has been described in a few children with severe chronic renal disease, e.g. hydronephrosis, polycystic kidneys, chronic glomerulo-nephritis, aplastic kidneys or renal tubular disease (Stryker, 1946; Andersen and Schlesinger, 1942; Cochrane and Bowden, 1954). Secondary hyperparathyroidism is ruled out as a cause of metastatic calcification in this patient because of the normal serum calcium and phosphorus levels and the normal blood urea despite amyloidosis of the kidney.

In infants, calcification of the coronary arteries with death from heart failure has been described by several authors (Baggenstoss and Keith, 1941; Andersen and Schlesinger, 1942; Stryker, 1946; Cochrane and Bowden, 1954; Hunt and Leys, 1957). The aetiology of the calcification in these cases was unknown and, although some of the large arteries were involved occasionally in addition to the coronaries, the digital vessels were not affected.

The rare condition of pseudoxanthoma elasticum, if widely disseminated, may be associated with calcification of the vessels due to an infiltration of the degenerated elastic tissue by calcium phosphate. This child, however, did not show the skin discolouration or eye changes associated with this disease. Neither did she have the skin changes of dermatomyositis which may be associated with subcutaneous deposits of calcium.

Vascular calcification in children has been described in hypervitaminosis $\mathbf{D}$ and also in severe forms of idiopathic hypercalcaemia (Schlesinger, Butler and Black, 1956; Rhaney and Mitchell, 1956). In retrospect, idiopathic hypercalcaemia was probably present in a similar case described by Lightwood (1932). In these conditions osteosclerosis occurs. Moreover there is no record of the present child having received extra vitamin $D$.

It is well known that hormone therapy may lead to osteoporosis and that in Cushing's syndrome renal calculi may form. However, no reference has been found to digital vessel calcification due to hormone therapy.

Acute and subacute forms of arteritis associated with rheumatoid arthritis have been discussed recently in the literature (Levin, Rivo, Scott, Figueroa, Fred and Barrett, 1953; Cruickshank, 1954; Kemper, Baggenstoss and Slocumb, 1957), but no mention has been made of calcification of the affected vessels.

Immobilization by bed-rest and particularly total immobilization in severe joint disease causes marked skeletal decalcification. Hypercalcaemia with renal calculi formation may follow but calcification of vessels has not been noted in the literature from this cause.

One cannot therefore be dogmatic regarding the aetiology of the digital vessel calcification in this child. It seems most likely, however, that prolonged immobilization led to decalcification of the skeleton with liberation of calcium which became deposited in digital vessels possibly damaged by rheumatoid disease.

\section{Summary}

A girl crippled by rheumatoid arthritis, complicated by amyloid disease, was found to have calcification of the digital vessels in association with widespread decalcification of the skeleton. After prednisolone therapy she was able to walk again. In the next three years considerable recalcification of the skeleton occurred with some diminution in the calcification of the digital vessels and marked regression in the amyloid disease.

I should like to thank Professor J. L. Henderson for his encouragement to publish this report, and Professor R. W. B. Ellis for access to the Edinburgh records. The calcium balance estimations were made by Dr. T. Bird, then of the Department of Pathology, Queen's College, and the photographs were prepared by Mr. T. King, Queen's College. 
REFERENCES

Andersen, D. H. and Schlesinger, E. R. (1942). Renal hyperparathyroidism with calcification of the arteries in infancy. Amer. J. Dis. Child., 63, 102.

Baggenstoss, A. H., and Keith, H. M. (1941). Calcification of the arteries of an infant. J. Pediat., 18, 95.

Cochrane, W. A. and Bowden, D. H. (1954). Calcification of the arteries in infancy and childhood. Pediatrics, 14, 222.

Cruickshank B. (1954). The arteritis of rheumatoid arthritis. Ann. rheum. Dis., 13, 136

Fischer, F. and Hastrup, B. (1954). Cortisone and calcium balance (effect of calcium, vitamin $\mathrm{D}$ and methylandrostenediol). Acta endocr. (Kbh.), 16, 141.

Holmes, J. O. (1945). The requirement for calcium during growth. Nutr. Abstr. Rev., 14, 597

Hunt, A. C. and Leys, D. G. (1957). Generalized arterial calcification of infancy. Brit. med. J., 1, 385.

Kemper, J. W., Baggenstoss, A. H. and Slocumb, C. H. (1957). The relationship of therapy with cortisone to the incidence of vascular lesions in rheumatoid arthritis. Ann. intern. Med., 46, 831 .
Levin, M. H., Rivo, J. B., Scott, W., Figueroa, W. G., Fred, L. and Barrett, T. F. (1953). The prolonged treatment of rheumatoid arthritis with cortisone and corticotropin. Amer. J. Med., 14,265

Lightwood, R. (1932). A case of dwarfism and calcinosis associated with widespread arterial degeneration. Arch. Dis. Childh., $7,193$.

Luder, J. (1954). Vertebral collapse after cortisone therapy. Gt. Ormond Str. J., No. 7, p. 15.

Parkins, R. A. and Bywaters, E. G. L. (1959). Regression of amyloidosis secondary to rheumatoid arthritis. Brit. med. J., 1, 536.

Rhaney, K. and Mitchell, R. G. (1956). Idiopathic hypercalcaemia of infants. Lancet, 1,1028 .

Schlesinger, B. E., Butler, N. R. and Black, J. A. (1956). Severe type of infantile hypercalcaemia. Brit. med. J., 1, 127.

Still, G. F. (1897). On a form of chronic joint disease in children. Med, Chir Trans, 80, 47.

Stryker, W. A. (1946), Arterial calcification in infancy with special reference to the coronary arteries. Amer. J. Path., 22, 1007.

Welch, R. G. and Forsyth, C. C. (1953). Still's disease treated with A.C.T.H. and cortisone. Gt Ormond Str. J., No. 5, p. 1. 